\title{
パイプクーリング効果の高精度予測に関する研究
}

\section{A STUDY ON HIGH ACCURATE PREDICTION OF PIPE COOLING EFFECT}

\author{
伊藤 洋*·坂口雄彦*·西山勝栄*·森 清就** \\ By Yo ITO, Takehiko SAKAGUCHI, Katsue NISHIYAMA and Kiyonari MORI
}

\begin{abstract}
The pipe cooling method is of use for control of thermal cracks in various massive concrete structures. This paper presents a new theoretical technique for solving the pipe cooling problems. The numerical computation is made by means of the modified Fluid in Cell (MFLIC) method which was developed for simulating energy equation with a large Péclet number. The experiment is done by using a large-sized rectangular concrete prism. Comparing theoretical results with experimental ones, the application technique of MFLIC method is confirmed. In addition, some characteristics of heat transfer at cooling pipe surface are theoretically clarified by the aid of computed results.

Keywords: mass concrete, pipe cooling, thermal crack, heat transfer, numerical analysis
\end{abstract}

\section{1.はじめに}

パイプクーリング工法は, 元来ダムコンクリートの熱 応力を低減させる方法の 1 つとして発展してきたもので あるが, 最近では原子力発電所や大型橋梁の橋脚などの 大型で重要なコンクリート構造物においても実施されつ つあり，多様化を呈してきている. そのため，クーリン グ効果に対する評価・解析にあたってはダム以外の構造 物にも適用し得るようできるだけ制約条件を少なくした 高精度の予測手法を確立する必要があり, 最近では田辺 $(1984)^{1)}$ や佐藤 $(1986)^{2)}$ らの研究によって, クーリン グ効果の三次元解析も可能となりつつある. しかしなが ら, 従来の評価・解析手法では, パイプ壁面での熱伝達 率を適切に与えることが条件となっており, クーリング 効果の理論的解明は必ずしも十分になされていないよう に思われる.

本論では, このような背景にあって, まず従来のコン クリートとパイプ内水おのおのの伝熱方程式より未知量 であるパイプ壁面熱流束項を消去することにより支配方

* 正会員 (株)熊谷組原子力開発室土木技術部 ( ₹ 162 新宿区津久戸町 $2-1)$

** 正会員 (株)熊谷組原子力開発室土木技術部課長 (同上)
程式を一本化し, 理論的に温度場を評価することを可能 にしたうえで, その解法に変形 FLIC 法を適用させて パイプクーリング周辺の伝熱を軸対称場において高精度 に解析する手法を提示する. また, その精度の検証にあ たっては大型供試体（幅・高さ $1 \mathrm{~m}$, 長さ $10 \mathrm{~m}$ ) を用 いたクーリング実験を実施し, その結果と解析結果を比 較・検討する. さらに, この予測手法を発展させ, 複雑 な三次元クーリング構造等に有効な従来解析手法・技術 の精度向上に必要となるパイプ壁面熱伝達率を理論的に 決定することを試み, 不明確であったそれの基本的性質 についても検討を加える. 得られた成果は, この種の予 測・評価精度を向上させるうえで有用と思われるのでこ こに報告する.

\section{2. 基礎式と変形 FLIC 法による解析法}

ここでは, 本論で用いるパイプクーリング解析の基礎 式とその解法について述べることとする.

パイプクーリング解析において従来用いられてきた基 礎式は, 次式に示すようにコンクリートとパイプ内水の $2 つ$ 場についておのおの独立した伝熱方程式で表わさ れている(1),2.

$$
(\rho c)_{c} \frac{\partial T_{c}}{\partial t}=\operatorname{div}\left(\varkappa_{c} \operatorname{grad} T_{c}\right)+q_{1}-q_{2}: \text { コンクリート }
$$


$(\rho c)_{w} \frac{\partial T_{w}}{\partial t}=-\operatorname{div}\left\{(\rho c)_{w}\left(v T_{w}\right)\right\}+q_{2}$ : パイプ内水

ここに, $(\rho c)$ : 熱容量, $T:$ 温度, $t$ : 時間, $x$ : 熱伝 導率, $q_{1}$ : コンクリートの内部発熱率, $q_{2}$ : コンクリー 卜からパイプ内水に吸収される熱吸収率 $\left(q_{2}=h\left(T_{c}-\right.\right.$ $\left.T_{w}\right), h$ : パイプ壁面の局所熱流束に係る係数), $v:$ パ イプ内水の流速, であり, 添字 $c, w$ はおのおのコンク リート, パイプ内水の諸量であることを表わす.

これらの 2 式を解くことによりコンクリートとパイプ 内水の温度分布が得られるわけであるが, その際両式に 含まれる熱交換流束項 $q_{2}$ は今日まで実験・経験的な值 を用いているのが現状である。しかし， $q_{2}$ に関与する 物理量は $f\left((\rho c)_{c},(\rho c)_{w}, T_{c}, T_{w}, x_{c}, x_{w}, q_{1}, \alpha, r_{\rho}, v\right.$, $L, R)=0,\left(こ こ に, \alpha\right.$ : 軀体表面熱伝達率, $r_{\rho}$ ：パイ プ半径, $L$ : 軀体長さ, $R$ : コンクリート厚さ）と多く 一義的に決めることは困難であり, 実験・経験的に求め るにはおのずと限界がある. そこで, 本論では上式 (1), （2）上り未知量 $q_{2}$ を消去し，一方パイプ内外表面の温 度はその管厚が非常に薄く, かつ熱伝導性も十分大きい ことからそれらを等しいと仮定することにより，パイプ 内水とコンクリート場の伝熱を同時に満足する伝熱方程 式を導くと,

$$
\begin{aligned}
& (\rho c)_{c} \frac{\partial T_{c}}{\partial t}+(\rho c)_{w} \frac{\partial T_{w}}{\partial t}=\operatorname{div}\left(\varkappa_{c} \operatorname{grad} T_{c}\right) \\
& -\operatorname{div}\left\{(\rho c)_{w}\left(v T_{w}\right)\right\}+q_{1}
\end{aligned}
$$

となる.

さらに，同式は全体系に対する伝熱方程式となってい るため, 定式化の便宜上任意の要素系に着目して一般的 な形に整理すると次式のように書くことができるる3/4).

$$
(\rho c) \frac{\partial T}{\partial t}=\operatorname{div}(\varkappa \operatorname{grad} T)-\operatorname{div}\left\{(\rho c)_{w}(v T)\right\}+q_{1}
$$

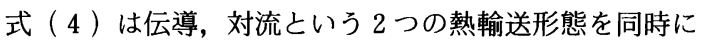
含む伝熱方程式であり, 上述の $q_{2}$ に係る物理量もすべ て含まれることになる. 同式を精度よく解析することに よりパイプクーリング周辺の伝熱現象を理論的に得るこ とが可能となるが，ここで対象とするような伝熱場では コンクリート中の伝導とパイプ内水の対流による熱輸送 量が大きく異なってくる. よって, 通常の有限要素法や 差分法では解析精度の大きく異なる伝導項と対流項を同 時に収束安定させることが難しく, 解の振動・発散を生 じ解析手法そのものにも工夫を要することになる．ここ では著者らがすでに平面二次元場における伝熱・移流分 散方程式のペクレ数 (Péclet number) の広い範囲にわ たる解法に提案している変形 FLIC 法を軸対称回転体

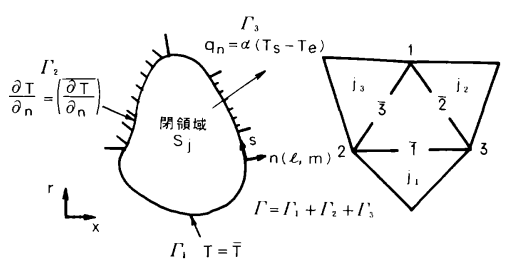

図一1軸対称場の境界と三角形要素

三次元場のそれに拡張・応用する4),5). FLIC (Fluid in Cell) 法は, 直交格子で分割された Cell 内の流体のも つ諸量 (質量, 運動量, エネルギー等) の時間的変化を 2 段階に分けて計算するというものであり, 流体運動を 記述する Lagrange, Euler の 2 通りの方法の特徵を有 している. 変形 FLIC 法は, FLIC 差分法を三角形領 域に拡張したものである. 以下にその変形 FLIC 法に よる定式化を具体的に述べる(4) -8).

まず，軸対称場における計算領域を図一1に示すよう に三角形に分割し, その中の任意の要素 $j$ に注目する. ここに, 図中の $i, \bar{i}(i=1,2,3)$ は三角形の頂点およ び対辺を意味する. また, $j, j_{i}(i=1,2,3)$ は三角形 の図心であるとする，そこで，基礎式 (4) を図一1の 任意の閉曲線内で面積積分し, 半径 $r$ の軸対称回転体 であることを考慮すると次のようになる.

$$
\begin{aligned}
& \int_{s_{j}} {\left[\frac{\partial T}{\partial t}+\operatorname{div}(\eta v T)\right] r d r d x } \\
& \quad=\int_{S_{j}}[\operatorname{div}(a \operatorname{grad} T)+\zeta] r d r d x
\end{aligned}
$$

ここに, $\eta=(\rho c)_{w} /(\rho c), \quad a=x /(\rho c), \quad \zeta=q_{1} /(\rho c), \quad S_{j}$ : 要素 $j$ の領域または面積である.

式（5）にGauss の発散定理を適用して整理すると 次式を得る.

$$
\begin{aligned}
& \int_{s_{j}} \frac{\partial T}{\partial t} \cdot r d r d x+\int_{r_{j}} \eta v_{n} T_{r} d s=\int_{\Gamma_{j}} \varepsilon_{n} r d s \\
& +\int_{s_{j}} \zeta r d r d x \\
& \left\{\begin{array}{ll}
\varepsilon_{n} \\
\varepsilon_{s}
\end{array}\right\}=\left(\begin{array}{cc}
l & m \\
-m & l
\end{array}\right)\left\{\begin{array}{l}
\varepsilon_{r} \\
\varepsilon_{x}
\end{array}\right\},\left\{\begin{array}{l}
\varepsilon_{r} \\
\varepsilon_{x}
\end{array}\right\}=a \operatorname{grad} T
\end{aligned}
$$

ここに, $\Gamma_{j}$ : 要素 $j$ を構成する境界, $v_{n}$ : 境界上にお ける $n$ 方向の速度, $l, m$ : 法線 $n$ の方向余弦, である. そこで, 上述したように変形 FLIC 法を適用して 2 段階に分けて差分化するため, 初めに式 (5) の左辺を Lagrange 微分で表わし, 式（6）を書き直すと次のよ うになる。

$$
\frac{D}{D t} \int_{s_{j}} r T d r d x=\int_{\Gamma_{j}} \varepsilon_{n} r d s+\int_{s_{j}} \zeta r d r d x
$$

ここで,

$$
\int_{s_{j}} r d r d x=S_{j} \frac{r_{G J}}{2}
$$




$$
\int_{\Gamma_{j}} r d s=R_{G \bar{i}} \frac{l_{\bar{i}}}{2}
$$

を考慮し，さらに Lagrange 微分を前進差分で近似し， それを時刻 $(n+1) \Delta t$ における中間的な值 $\tilde{T}_{j}$ につい て整理すると,

$$
\tilde{T}_{j}=T_{j}^{(n)}+\frac{\Delta t}{S_{j} r_{G j}}\left\{\sum_{i=1}^{3} \varepsilon_{n \bar{l}} R_{G \bar{i}} \cdot l_{\bar{i}}+\zeta_{j}^{(n)} S_{j} r_{G j}\right\}
$$

となる.ここに， $T_{j}^{(n)}$ : 要素 $j$ における時刻 $t=n \Delta t$ で の温度, $r_{G j}$ : 三角形要素 $j$ の図心の $r$ 座標 $\left(r_{G j}=\left(r_{1}\right.\right.$ $\left.\left.+r_{2}+r_{3}\right) / 3\right), \varepsilon_{n \bar{i}}:$ 辺 $\bar{i}$ を共有する 2 要素の平均値, $R_{G \bar{i}}$ : 辺 $\bar{i}$ の構成節点の $r$ 座標の和（たとえば $R_{G \overline{1}}=$ $\left.r_{2}+r_{3}\right), l_{\bar{i}}:$ 辺 $\bar{i}$ の長さ, である.

次に，第 2 段階では式（6)，（7）の左辺を等置する ことにより,

$$
\frac{D}{D t} \int_{s_{j}} r T d r d x=\int_{s_{j}} \frac{\partial T}{\partial t} r d r d x+\int_{\Gamma_{j}} \eta v_{n} T r d s
$$

となり，これを離散化すると，

$$
\frac{\left(\tilde{T}_{j}-T_{j}^{(n)}\right) S_{j} r_{G j}}{\Delta t}=\frac{\left(T_{j}^{(n+1)}-T_{j}^{(n)}\right) S_{j} r_{G J}}{\Delta t}+\sum_{i=1}^{3} l_{\bar{i}} P_{\bar{i}} R_{G \bar{i}}
$$

となる. したがって時刻 $t=(n+1) \Delta t$ における温度 $T_{j}^{(n+1)}$ は次のように導かれる.

$$
T_{j}^{(n+1)}=\tilde{T}_{j}-\frac{\Delta t}{S_{j} r_{G j}} \cdot \sum_{i=1}^{3} l_{\bar{i}} P_{\bar{i}} R_{G \bar{i}}
$$

ここで， $P_{\bar{i}}$ は風上差分の考え方を導入して次のように 表わす.

$$
\begin{array}{ll}
P_{\bar{i}}=\eta v_{n \bar{i}}\left\{\delta_{i} \tilde{T}_{j \bar{i}}+\left(1-\delta_{i}\right) \tilde{T}_{j}\right\} \cdots \cdots \cdots \cdots \cdots \cdots \cdots \cdots \cdots \cdots \cdots \cdots \cdots \cdots \cdots \cdots \\
\delta_{i}=\delta & v_{n \bar{i}}<0 \text { (辺 } \bar{i} \text { を通じて流入) } \\
\delta_{i}=1-\delta & v_{n \bar{i}}>0 \text { (辺 } \bar{i} \text { を通じて流出) }
\end{array}
$$

ここに， $\delta$ は上流パラメーターで $0.5 \leq \delta \leq 1.0$ の值を とり,解の精度・収束性を考慮して決定することになる.

一般的に $\delta$ が 0.5 に近いほど解の精度が増し, 逆に 1.0 に近いと収束性がよくなるといった傾向がある. 後述の 解析では収束性を重視し， $\delta=1.0$ ととる.

以上が変形 FLIC 法による定式化の概要であり, 境 界条件は以下の Dirichlet, Neumann, 対流熱伝達型の 境界を設定する.

$$
\begin{aligned}
& T=\bar{T} \text { on } \Gamma_{1}, \quad \partial T / \partial n=\overline{\partial T / \partial n} \text { on } \Gamma_{2} \\
& q_{n}=\alpha\left(T_{s}-T_{e}\right) \text { on } \Gamma_{3}
\end{aligned}
$$

ここに, $q_{n}$ : 単位面積当たりの熱流束, $\alpha$ : 軀体表面熱 伝達率, $T_{s}$ : コンクリート表面の温度, $T_{e}:$ 外気温で あり,一（バー）はその境界において既知であることを 表わす.

したがって, 式 (10)，(13）を式（15）の境界条件下 で解くことによりコンクリートとパイプ内水の温度場を 同時に求めることができる.

\section{3. 実験結果と解析結果の比較・検討}

\begin{tabular}{|c|c|c|c|c|c|c|c|c|}
\hline \multirow{2}{*}{ 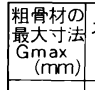 } & \multirow{2}{*}{$\begin{array}{l}\text { スランフ } \\
(\mathrm{cm})\end{array}$} & \multirow{2}{*}{$\begin{array}{c}\text { 空気量 } \\
(\%)\end{array}$} & \multirow{2}{*}{$\begin{array}{r}W / C \\
(\%)\end{array}$} & \multirow{2}{*}{$\begin{array}{l}\text { s/a } \\
(\%) \\
\end{array}$} & \multicolumn{2}{|c|}{ 单 位 } & \multicolumn{2}{|c|}{ 锤 $\left(\mathrm{N} / \mathrm{m}^{3}\right)$} \\
\hline & & & & & W & C & $\mathrm{s}$ & G \\
\hline 15 & 12 & 4 & 54.8 & 44.8 & 1,934 & 3,528 & 7.419 & 10.564 \\
\hline
\end{tabular}

\section{（1）パイプクーリング実験}

2. で述べた解析手法の妥当性を確認し, また, パイ プクーリング効果の基本的性質を調べるため, 大型供試 体を用いたパイプクーリング実験を実施する.

本実験に用いた供試体の概要を図一2に示す。供試体 は，パイプクーリングを実施するクーリング供試体（同

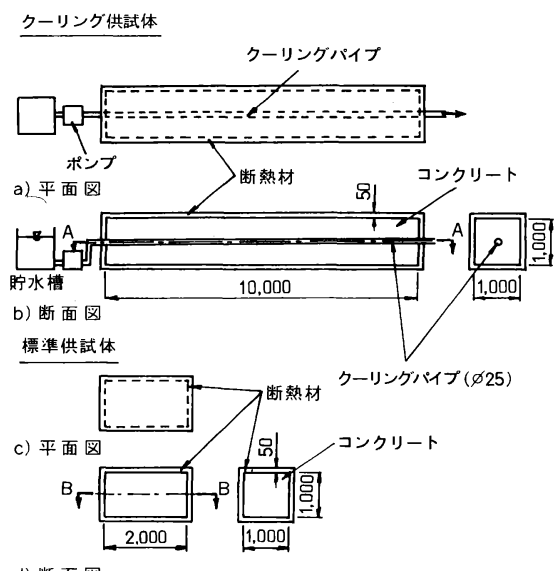

d) 断面図

図-2 実験供試体概要（単位: $\mathrm{mm}$ )

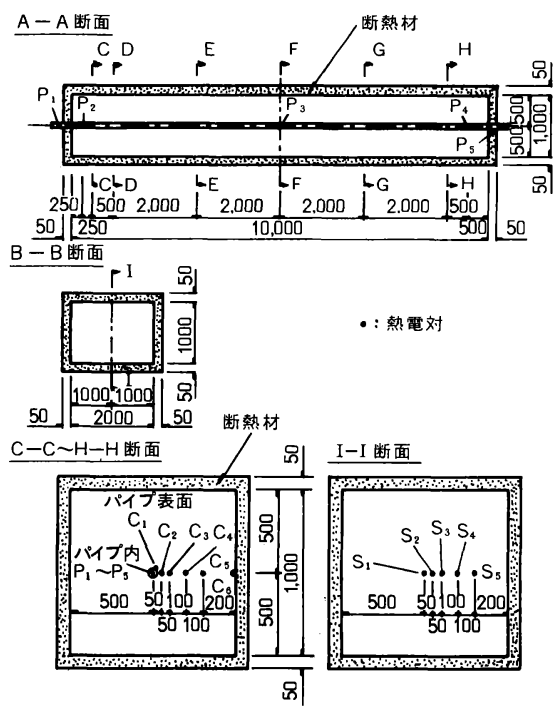

図一3 計測位置 (単位: $\mathrm{mm}$ ) 
図上)とそれを行わない標準供試体（下）の 2 体である. 前者は, 幅, 高さとも $1 \mathrm{~m}$ の正方形断面で長さ $10 \mathrm{~m}$ の 直方体コンクリート軀体であり, 中心には内径 $r_{p}=25$ $\mathrm{mm}$ の薄肉電縫鋼管が設置されている. また, 供試体の 周囲すなわち型枠の内側および供試体上部には, 表面放 熱を防止するために厚さ $50 \mathrm{~mm}$ の断熱材 (発泡スチロー ル製）が取り付けてある. 一方，後者は前者と同断面を 有する長さ $2 \mathrm{~m}$ の無筋コンクリート軀体であり, 同様 に全面が断熱材で覆われている.

コンクリートの打設は両供試体とも同時に行われた が，クーリング供試体においては打設開始と同時にポン プを始動し, クーリングパイプ内に毎分 $15 l$ (流速 $v=$ $0.5 \mathrm{~m} / \mathrm{s}$ ) の水道水 (常温) を材令 35 時間まで通水する. 使用したコンクリートの配合は表一1に示すとおりであ り, セメントは普通ポルトランドセメントを使用してい る.

計測は， T 型熱電対およびディジタル温度測定器に よって打設開始時より材令 45 時間まで行われ，コンク リートおよびパイプ内水の温度分布の経時変化が自動測 定・記録される．温度計測のための熱電対設置位置を図 -3に示す. 計測点は, パイプ内水については 5 点 $\left(P_{1}\right.$ $\left.\sim P_{\mathrm{s}}\right)$, コンクリート内部はクーリング供試体で 5 断面 (C-C $\sim \mathrm{H}-\mathrm{H}$ 断面) で各 6 点 $\left(C_{1} \sim C_{6}\right)$, 標準供試体 の 1 断面 (I-I 断面) で 5 点 $\left(S_{1} \sim S_{5}\right)$ の計 40 点である.

\section{（2）解析モデルと条件}

本解析に用いた解析モデルは, 上述の実験と条件を整 合させるため，図一4に示すような長さ $L=10.0 \mathrm{~m}$ で 半径 $r_{p}=0.0125 \mathrm{~m}$ のパイプを中心とした軸対称回転体 三次元モデルとする. クーリング水は左から右へ流速 $v$ $=0.5 \mathrm{~m} / \mathrm{s}$ (断面一様) で流れており, 半径 $R_{1}=0.5 \mathrm{~m}$ のコンクリート軀体は全周にわたり厚さ $R_{2}=0.05 \mathrm{~m}$ の
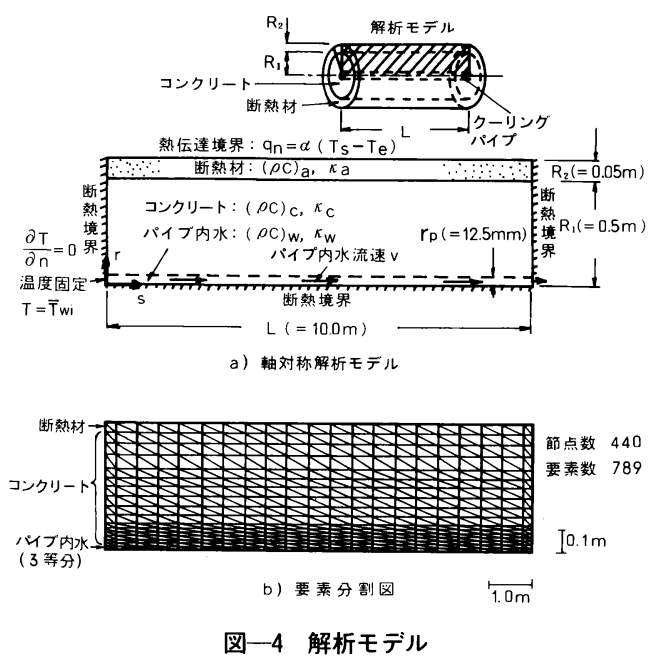

表一2 解析に用いた諸定数

\begin{tabular}{|c|c|}
\hline コンクリートの熱容量 $(\rho \mathrm{C})_{\mathrm{c}}$ & $\mathrm{MJ} / \mathrm{m}^{3} \mathrm{~K}$ \\
\hline コンクリートの熱伝導率 $\kappa_{C}$ & $\mathrm{w} / \mathrm{mK}$ \\
\hline 断熱材の熱容 量 $(\rho \mathrm{C}) \mathrm{a}$ & $\mathrm{kJ} / \mathrm{m}^{3} \mathrm{~K}$ \\
\hline 断熱材の熟伝導率 $\quad \kappa a$ & $\mathrm{~W} / \mathrm{mK}$ \\
\hline 水 $の$ 熱 容 量 $(\rho \mathrm{C})_{\mathrm{w}}$ & $\mathrm{MJ} / \mathrm{m}^{3} \mathrm{~K}$ \\
\hline 水の熱 伝導率 $\kappa_{\mathrm{w}}$ & $\mathrm{W} / \mathrm{mk}$ \\
\hline 断熱材表面の熱伝達率 & $w / m^{2} k$ \\
\hline パィプ内 水流速 & 0.50 \\
\hline モ & 10.0 \\
\hline デ パイプ半径 $r_{p}$ & 0.0125 \\
\hline 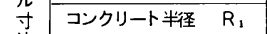 & 0.50 \\
\hline 法 断 熱 材 厚 $\mathrm{R}_{2}$ & 0.05 \\
\hline コンクリートの断熱温度上昇式 & $\mathrm{Ta}\left({ }^{\circ} \mathrm{C}\right)=50\left(1-\mathrm{e}^{-2 \mathrm{t}}\right), \mathrm{t}(\mathrm{d})$ \\
\hline 打設時のコンクリート温 度 & 24.0 \\
\hline パィプ内水入口の水温 & $22.0 \sim 24.0^{\circ} \mathrm{C}$ \\
\hline
\end{tabular}

断熱材で覆われているものとする. 解析は, 同図上部に 示したような半断面 (図中斜線部) について軸対称解析 を行うが, 境界条件は, パイプ部左端が温度固定 (Dirichlet) 境界 $\Gamma_{1}\left(T=\bar{T}_{w i}, \bar{T}_{w i}\right.$ : 流入水温度), モ デル周囲の断熱材表面が熱伝達境界 $\Gamma_{3}\left(q_{n}=\alpha\left(T_{s}-\right.\right.$ $\left.T_{e}\right)$ ) であり, それ以外は断熱 (Neumann) 境界 $\Gamma_{2}$ $(\partial T / \partial n=0)$ とする. 表一 2 には本解析に用いた諸定 数を示している. コンクリート, 断熱材, パイプ内水の 熱容量はおのおの $(\rho c)_{c}=2.2,(\rho c)_{a}=31.4,(\rho c)_{w}=4.2$ $\mathrm{MJ} / \mathrm{m}^{3} \mathrm{~K}$ ，熱伝導率は $x_{c}=2.3 ， x_{a}=0.041, x_{w}=0.6$ $\mathrm{W} / \mathrm{mK}$ とし, 断熱材表面の熱伝達率は $\alpha=11.63$ $\mathrm{W} / \mathrm{m}^{2} \mathrm{~K}$ とする. また, コンクリートの断熱温度上昇は, 上述の実験結果 (標準供試体 I-I 断面中心温度 $T_{s 1}$, 図 一3 参照) より得た近似式, $T_{a}\left({ }^{\circ} \mathrm{C}\right)=50\left(1-e^{-2 t}\right)$ を 用いる. なお, 解析時間きざみは, クーラン数 $C_{r}=$ $v \Delta t / \Delta s<0.5(v=0.5 \mathrm{~m} / \mathrm{s}, \Delta s=0.25 \mathrm{~m})$ より $\Delta t=$ $6.25 \times 10^{-5} \mathrm{~h}$ ととる ${ }^{9)}$.

\section{（3）実験・解析結果とその考察}

実験により得られた結果のうち代表的なものを示し, パイプクーリング実施による冷却効果の基本的性質につ いて考察しつつ, 本手法による解析結果と比較検討する.

初めに, 図一5 はクーリング供試体長手方向のコンク リート温度分布の経時変化をみるため, 図一3 中の A-A 断面におけるそれを材令 $t=6,12,18,24 \mathrm{~h}$ につ いて示したものである. 図中には, 測点 $C_{2}, C_{3}, C_{4}, C_{5}$ の温度実測値 (図中・) と解析值 (図中破線) を同時に 示している. これより, 当然ながらコンクリート温度は クーリングパイプに近い点 $C_{2}$ においてクーリング効果 が最も大きいために低く，それより離れるに従って高く なっているが, 全体的には経時的に上昇しつつ各点の温 度差が広がる傾向にあることが認められる. 実験值と解 析値を比較すると全体的によく一致している. 


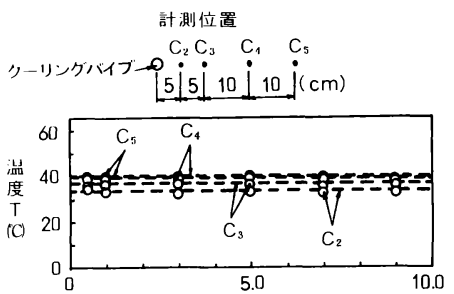

a) 材令 $t=6 \mathrm{~h}$

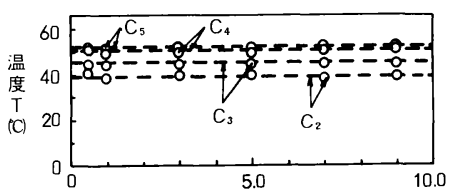

b) 材令 $t=12 h$

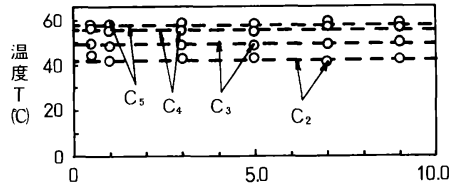

c) 材令 $\mathrm{t}=18 \mathrm{~h}$

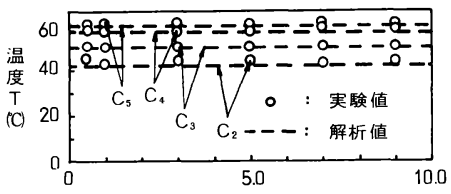

d) 材令 $\mathrm{t}=24 \mathrm{~h}$

図一5 長手方向コンクリート温度分布の経時変化（図一-3 A-A 断面)

次に，供試体長手方向直交断面である F-F 断面にお ける測定温度の経時変化を示した図一6に着目する.図 中, 実線 $T_{P 3}$ はパイプ内水温, $T_{c 2} \sim T_{c 5}$ はおのおのパ

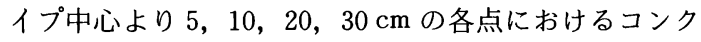
リート温度, 一点鎖線 $T_{s 1}$ は標準供試体中央断面 (I-I 断面）の中心温度である. また, 破線は解析值であり, 点線は $T_{s 1}$ の実測値より近似した断熱温度上昇曲線 $\left\{T_{a}\right.$ $\left.=50\left(1-e^{-2 t}\right), t(d)\right\}$ を示している. 図より, パイ プ内水温 $T_{P 3}$ は計測期間を通じてほとんじ変化は認めら れないが，コンクリート温度 $T_{c 2} \sim T_{c 5}$ はいずれも材令 2 時間頃より急激に上昇し, 徐々に緩やかになって材令 20 時間を経過するとほぼ一定值となることがわかる. 各点の温度はクーリングパイプに近いほど低いことが確 認できる. クーリング効果は断熱上昇温度 $T_{a}$ との差と いうことになるが, 今回の実験では $10 \sim 30^{\circ} \mathrm{C}$ 程度低減 されている. クーリング停止材令 $(35 \mathrm{~h})$ 後はパイプに 近い点ほど急激に温度上昇し，いずれも数時間後には $T_{c 5}$ に一致してくることが読み取れる. 解析値は打設直 後に実験值より若干低くなっているが，その後はよく追 随・再現している. この若材令時の差異は打設時刻の時 間・空間的ばらつきや環境条件変化等によるものと考え

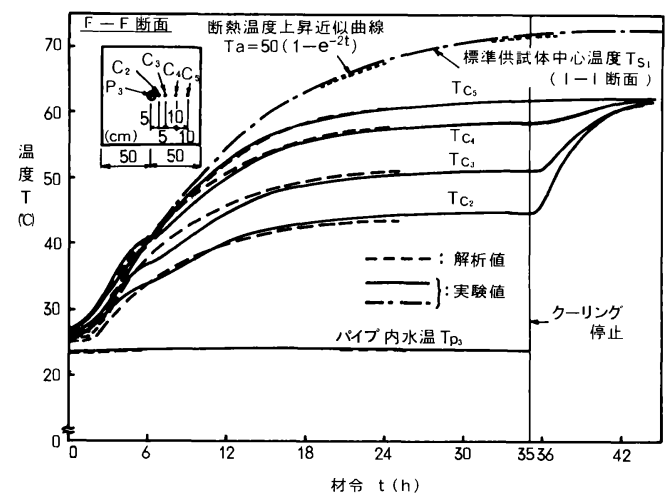

図一6 クーリングパイプ周辺測点におけるコンクリート温度の 経時变化 (F-F 断面)

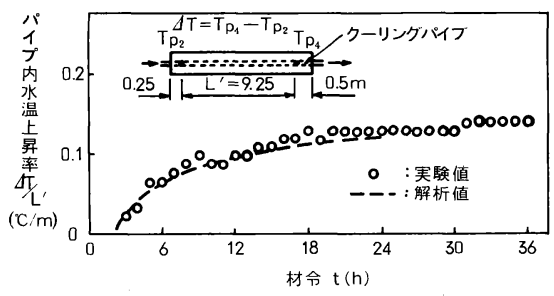

図一7 パイプ内水温上昇率の経時変化
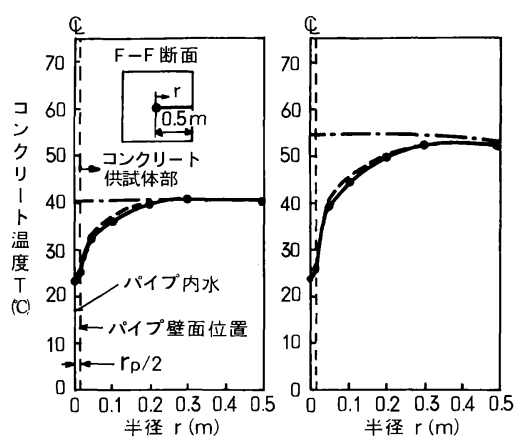

a) 材令 $t=6 h$

b) $t=12 h$
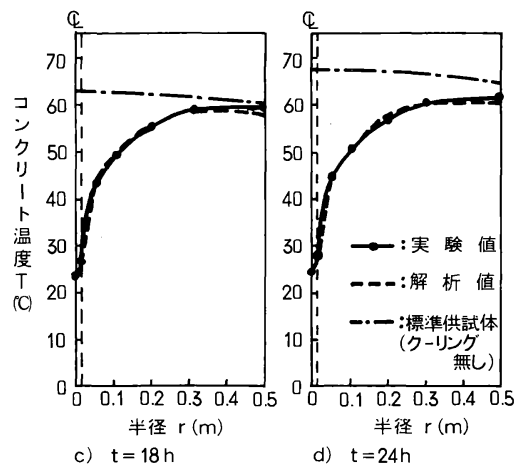

図一8 クーリングパイプ周辺における温度分布の経時変化 (F-F 断面) 
得る.

一方, 図一7はパイプ内水温の流水方向上昇率 $\Delta T / L^{\prime}$ の経時変化を示したものである.ここで, $\Delta T$ $=T_{P 4}-T_{P 2}$ であり, $L^{\prime}$ はその間の距離である. パイプ 内水温は図一6に示したコンクリート温度の上昇に対応 して材令 2 時間頃より上昇し始め，材令 20 時間を超え るとほぼ一定の值 $\left(\Delta T / L^{\prime} \fallingdotseq 0.13^{\circ} \mathrm{C} / \mathrm{m}, \Delta T \fallingdotseq 1.2^{\circ} \mathrm{C}\right)$ となっている. 水温上昇はこのようにかなり微妙な值で あるが，この場合においても解析值は実験結果とよく整 合しており，十分な精度を得ている.

図一8 は，図一6と同じ F-F 断面におけるパイプ周 辺の温度分布の経時変化を示したものである. 図中, 実 線は実験值，一点鎖線は標準供試体温度，破線は解析値 である．同図においても標準供試体温度との差がクーリ ング効果を表わすことになる．これより，パイプ近傍で の温度勾配は経時的に大きくなり，クーリング効果の影 響半径も広がってくることが認められる．ただ，ある時 間を経過するとコンクリート温度自体はしだいに安定し てくることになる．解析值と実験值はこのような断面温 度分布をとってもよく一致している。

\section{4. パイプ壁面熱伝達率の理論的決定}

2. で提示した解析手法を応用し，ここでは従来技術 の精度向上にあたって大切となるパイプ壁面熱伝達率を 理論的に算定・決定することを試み，また従来未解明で あったそれの基本的性質についても検討を加える.

\section{（1）熱伝達率の決定法}

熱伝達率を算定するにあたり，まずよく知られている クーリングパイプ内水の熱収支を示した図一9に着目す る.ここで，パイプ内水は乱流であって断面流速分布は 一様であるとする．同図より，微小部分 $d s$ における熱 収支およびコンクリートと水の間の熱流束 $Q$ は，パイ プ半径 $r=r_{\rho}$, 断面積 $A\left(=\pi r_{\rho}^{2}\right)$, 平均水温 $T_{w}$, パイ プ壁面位置 $\left(r=r_{p}\right)$ でのコンクリート温度 $T_{c s}$, パイ プ壁面熱伝達率 $\alpha_{w}$ を定義すると式（2）より次式のよ うに表わすことができる1),21.

$$
\begin{aligned}
& (\rho c)_{w} \frac{\partial T_{w}}{\partial t} A d s=-(\rho c)_{w} v \frac{\partial T_{w}}{\partial s} A d s+Q \cdots \\
& Q=q_{2} A d s=2 \pi r_{p} d s \alpha_{w}\left(T_{c s}-T_{w}\right) \cdots \cdots \cdots \cdots \cdots
\end{aligned}
$$

これより，式（17）を式（16）に代入し整理すると結果 的に $\alpha_{w}$ は,

$$
\alpha_{w}=-\frac{(\rho c)_{w} r_{p} v}{2\left(T_{w}-T_{c s}\right)}\left(\frac{\partial T_{w}}{\partial s}-\frac{1}{v} \frac{\partial T_{w}}{\partial t}\right)
$$

と書くことができる．同式において， $(\rho c)_{w}, r_{p}, v$ は既 知量であるから，3. で示したような解析結果を利用し 乙 $T_{w}, T_{c s}, \partial T_{w} / \partial t, \partial T_{w} / \partial s$ の時間・位置的分布を整 理・代入することにより理論的に $\alpha_{w}(s, t)$ を算定・決

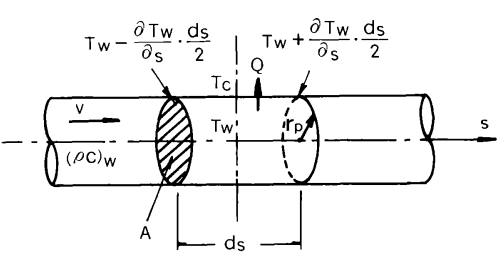

\begin{tabular}{|c|c|c|c|}
\hline \multicolumn{2}{|c|}{ コンクリートの熱容量 $(\rho C) \mathrm{C}$} & 2.2 & $\mathrm{MJ} / \mathrm{m}^{3} \mathrm{~K}$ \\
\hline \multicolumn{2}{|c|}{ コンクリートの熱伝道率 $\kappa_{C}$} & 2.7 & $\mathrm{~W} / \mathrm{mK}$ \\
\hline \multicolumn{2}{|c|}{ パイプ内水の熱容量 $(\rho \mathrm{C})_{\mathrm{W}}$} & 4.2 & $\mathrm{MJ} / \mathrm{m}^{3} \mathrm{~K}$ \\
\hline \multicolumn{2}{|c|}{ パイプ内水の熱伝導率 } & 0.60 & $\mathrm{~W} / \mathrm{mK}$ \\
\hline \multicolumn{2}{|c|}{ バィプ内水流速 $v$} & \multicolumn{2}{|c|}{$02,0.4,0.6 \mathrm{~m} / \mathrm{s}$} \\
\hline \multirow{3}{*}{ モデル寸法 } & $\mathrm{L}$ & 10.0 & $m$ \\
\hline & パイブ半径 $r_{p}$ & 0.0125 & $m$ \\
\hline & コンクリート半径 R & 1.0 & $m$ \\
\hline \multicolumn{2}{|c|}{ コンクリートの断熱温度上昇式 } & \multicolumn{2}{|c|}{$T_{b}=37.3\left(1-e^{-093 t}\right), t(d)$} \\
\hline \multicolumn{2}{|c|}{ 初 $\quad$ 期 $\quad$ 温 $\quad$ 度 } & 20.0 & C \\
\hline \multicolumn{2}{|c|}{ パイプ内水入口の水温 } & 15.0 & ${ }^{\circ} \mathrm{C}$ \\
\hline
\end{tabular}

図一9 クーリングパイプ内の熱収支

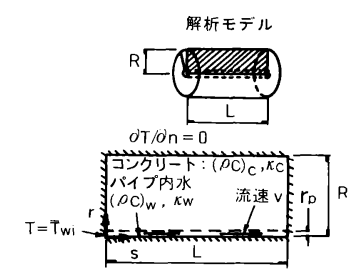

図一10 解析モデルと諸条件

定することが可能となる.

\section{（2）解析モデルと条件}

上述した手法を用い，図一10に示したようなモデル・ 諸条件を設定してパイプ壁面熱伝達率の基本的な性質を 吟味してみることとする. 解析モデルは, 中心に半径 $r_{p}=0.0125 \mathrm{~m}$ のパイプを有する長さ $L=10 \mathrm{~m}$, 半径 $R$ $=1.0 \mathrm{~m}$ の断熱状態にあるようなコンクリート軀体を設 定し, 解析はその軸対称断面 (図中斜線部) について実 施する. 要素分割は図一4b) に示したものとほぼ同様 であり,パイプ内は $r$ 軸方向に 3 分割とする. 伝熱物 性值は, 同図中に示したようにコンクリートおよびパイ プ内水の熱容量 $(\rho c)_{c}=2.2,(\rho c)_{w}=4.2 \mathrm{MJ} / \mathrm{m}^{3} \mathrm{~K}$, 熱 伝導率 $x_{c}=2.7, x_{w}=0.60 \mathrm{~W} / \mathrm{mK}$ とし，コンクリート の断熱温度上昇式は普通ポルトランドセメント 300 $\mathrm{kgf} / \mathrm{m}^{3}$ を用いたような場合を想定し， $T_{b}=37.3(1-$ $\left.e^{-0.93 t}\right), t(d)$ とする ${ }^{10)}$. また, 境界条件はパイプ内水 入口の水温を $15.0^{\circ} \mathrm{C}$ の温度固定境界とし, それ以外は すべて断熱境界とする. 解析は, パイプ内水流速を $v=$ $0.2,0.4,0.6 \mathrm{~m} / \mathrm{s}$ と変えた 3 ケースについて, 材令 48 時間までの非定常伝熱解析を実施する.

\section{（3）熱伝達率の基本的性質}

上述したように熱伝達率を算定するにあたり必要とな る（式（18）参照）パイプ内水温度 $T_{w}$, パイプに隣接 


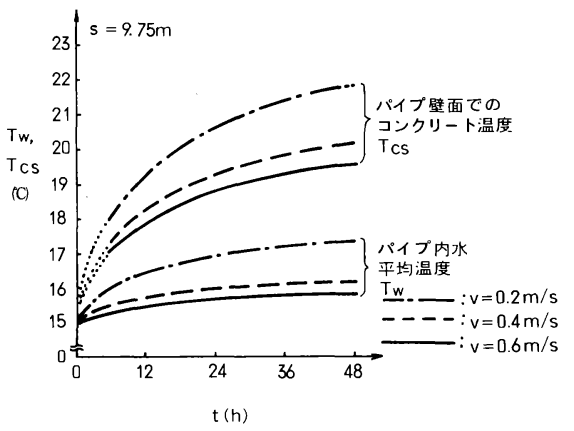

図一11 $\boldsymbol{s}=9.75 \mathrm{~m}$ 位置における $\boldsymbol{T}_{w}, \boldsymbol{T}_{c s}$ の経時変化

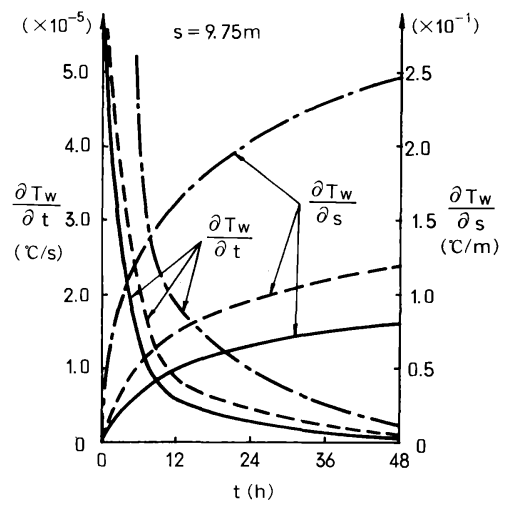

図一12 $s=9.75 \mathrm{~m}$ 位置における $\partial T_{w} / \partial t, \partial T_{w} / \partial s$ の経時変 化

するコンクリート温度 $T_{c s}, T_{w}$ の単位時間・距離当たり の変化率 $\partial T_{w} / \partial t, \partial T_{w} / \partial s$ の時間・位置的分布の代表 的なものを提示し，それぞれの基本的性質を検討したう えで最終的に $\alpha_{w}$ を算定してみることとする.

まず, $s=9.75 \mathrm{~m}$ 位置における $T_{w}, T_{c s}$ および $\partial T_{w} / \partial t, \partial T_{w} / \partial s$ の経時変化を, 流速 $v=0.2 \mathrm{~m} / \mathrm{s}$ （一 点鎖線), $0.4 \mathrm{~m} / \mathrm{s}$ (破線), $0.6 \mathrm{~m} / \mathrm{s}$ (実線) をパラメー ターにして示したものが図一11，12である．3. ですで に述べたように，コンクリート温度 $T_{c s}$ が上昇するにつ れ承温 $T_{w}$ およびその上昇率 $\partial T_{w} / \partial s$ は上昇するが, 経時的にそれらの上昇勾配は徐々に減少し一定値に漸近 してくることが確認できる．逆に $\partial T_{w} / \partial t$ は減少する こととなる. また，パイプ内水の流速による影響も顕著 に現われ，それが速いほどコンクリート，水の温度およ び水温上昇率は小さくなることがわかる. つまり，水の 速度が速いとそれだけ熱輸送量が大きくなるわけで，コ ンクリートからの熱流束がそれに比して増大しない限り 水温上昇が小さくなることは十分納得できる.

図一13, 14 は，おのおの材令 $t=24 \mathrm{~h}$ における $T_{w}$, $T_{c s}$ および $\partial T_{w} / \partial t, \partial T_{w} / \partial s$ のパイプ軸方向の分布を 示したものである. $T_{w}, T_{c s}$ はパイプ流入端からの距離

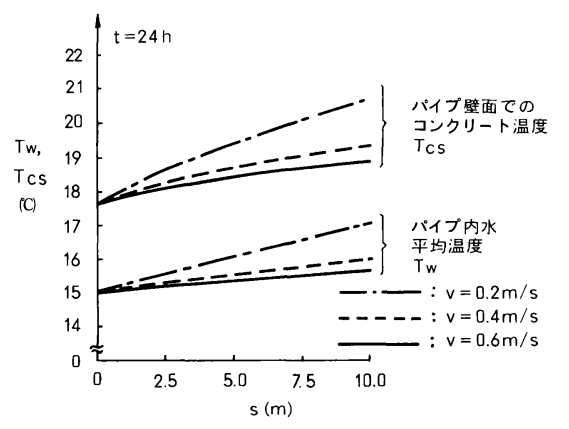

図一13 材令 $t=24 \mathrm{~h}$ における $T_{w}, T_{c s}$ の位置的变化

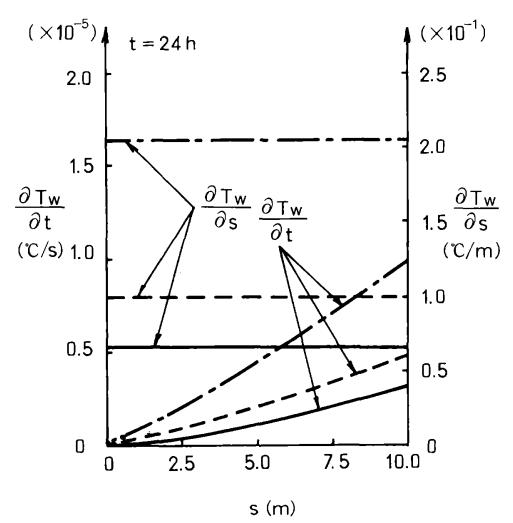

図一14 材令 $t=24 \mathrm{~h}$ における $\partial T_{w} / \partial t, \partial T_{w} / \partial s$ の位置的変 化

$s$ に比例して上昇するが, $\partial T_{w} / \partial s$ は一定値となって位 置による変化はほとんど現われない。一方， $\partial T_{w} / \partial t$ は $s=0 \mathrm{~m}$ で温度固定としているので流入口より離れるに 伴って増大することとなっている. 当然ながらこの場合 もパイプ内流速が速いほど温度およびその上昇率は小さ い.

次に，図一11〜14で示した解析結果を踏まえ上述の 手順に従ってパイプ壁面熱伝達率 $\alpha_{w}$ を決定し, その基 本的性質を調べてみることとする，まず，図一15 は $s$ $=2.5 \mathrm{~m}$ および $9.75 \mathrm{~m}$ 位置における $\alpha_{w}$ の経時変化を $v$ $=0.2,0.4,0.6 \mathrm{~m} / \mathrm{s}$ の場合について示したものである. $\alpha_{w}$ は流入端に近く, また水流速が速いと若干大きい值 をもつが，経時的にはほとんど変化せず，一定値となっ ている， $\alpha_{w}$ の時間依存性が小さいことは, 式（18）に おいて流速 $v=0.2 \sim 0.6 \mathrm{~m} / \mathrm{s}$ の範囲ではごく初期を除 いて図一12 から $\partial T_{w} / \partial s \gg 1 / v \cdot \partial T_{w} / \partial t$ となることか ら十分理解できる. 一方, 図一16 は材令 $t=24 \mathrm{~h}$ にお ける $\alpha_{w}$ の位置的変化について示したものである. $\alpha_{w}$ は 流入口で大きくそれから離れるに従って減少しつつしだ いに一定値に漸近してくることが認められる．このとき $\alpha_{w}$ は流入端近傍では流速による差は小さく, いずれも 


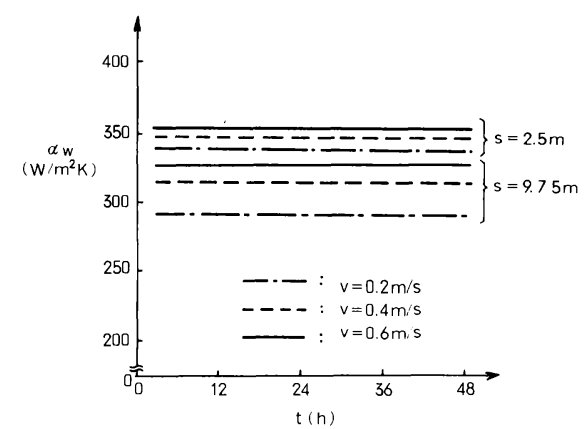

図一15 パイプ壁面熱伝達率 $\boldsymbol{\alpha}_{w}$ の経時变化

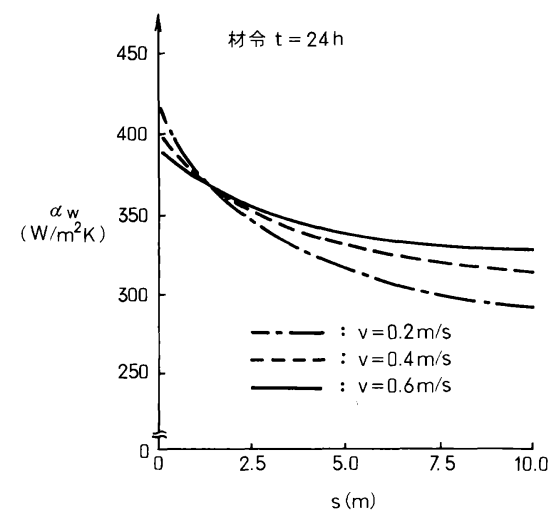

図一16 材令 $\boldsymbol{t}=24 \mathrm{~h}$ におけるパイプ壁面熱伝達率 $\boldsymbol{\alpha}_{w}$ の位置的 変化

$400 \mathrm{~W} / \mathrm{m}^{2} \mathrm{~K}$ 前後の值をとっているが, それから離れる と差を生じ，全体的に流速の速い方が大きい．この場合 の変化は, 式 (18) において $v, \partial T_{w} / \partial s($ 図一14）は 一定值であるから, 温度差 $\left(T_{w}-T_{c s}\right)$ (図一13) の増 大に起因したものと判断できる.

以上のようにして得られた本モデルにおけるパイプ壁 面熱伝達率 $\alpha_{w}$ をパイプ内水流速 $v$ との関係に整理する と図一17のようになる. 同図には参考のため田辺らに より実験から導かれた平均熱伝達率算定式 $\alpha_{w r}\left(\mathrm{~W} / \mathrm{m}^{2}\right.$ $\mathrm{K}) \approx 552 v+50$ によるものも併せて示してある（図中破 線 $)^{11}$. 本解析により得られた $\alpha_{w}$ は流速が大きいと若干 増大するものの, それの依存性は小さいこととなってい る.これは, 式（18）において図一14に示したように $v$ が大きいと逆に $\partial T_{w} / \partial s$ が小さくなるといった関係 から結局はお互いに相殺されて流速依存性が現われてこ

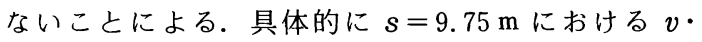
$\partial T_{w} / \partial s$ を計算してみると, $v=0.2 \mathrm{~m} / \mathrm{s}$ のときは 4.09

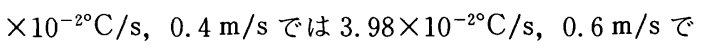
は $3.94 \times 10^{-2 \circ} \mathrm{C} / \mathrm{s}$ とほとんど同一の値となっている. 一方, 温度差 $\left(T_{w}-T_{c s}\right)$ は図一13にみられるように 大きな差はない. また, 熱輸送量はパイプ内水の方がコ

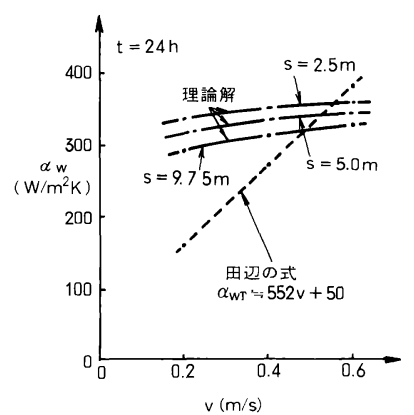

図一17 材令 $t=24 \mathrm{~h}$ におけるパイプ壁面熱伝達率 $\boldsymbol{\alpha}_{w}$ とパイプ 内水流速 $v$ の関係

ンクリート部の熱伝導伝熱によるものより十分大きく, 熱交換流束はむしろコンクリート部におけるそれの能力 によって決まってくることを考えれば，熱伝達率は必ず しも流速に依存したものでないことが示唆される. 田辺 式との差異は, 実験が温水注入方式であったことなどい くつかの要因が考えられるが, 通常クーリングを行う場 合の流速 $0.4 \sim 0.6 \mathrm{~m} / \mathrm{s}$ 程度ではいずれも適切な值を与 えているものと考え得る. 結局, パイプ内水の流速は, パイプ壁面熱伝達率にはあまり影響を与えないが，水温 上昇率が大きく変化しクーリング効果を支配することが 示唆される結果となった。

\section{5. 結 論}

本研究ではパイプクーリング効果を理論的に評価し得 る手法を提案し，大型実験供試体を用いてその妥当性・ 精度を吟味した. さらに, それらの手法を発展させ, 理 論・解析的にパイプ壁面熱伝達率を決定することを試 み, 従来明確でなかったそれの基本的性質を解明し得た. 本研究で得られた成果は以下のように要約される.

（1）パイプクーリング周辺の伝熱場は, 伝導, 対流 項を含む 1 つの移流伝熱方程式を用いることにより理論 的に評価し得ることを確認した。

（2）軸対称二次元移流伝熱方程式の解法に変形 FLIC 法を適用し, クーリングパイプ周辺の伝熱場の精 度よい解を得ることができた。

（3）単位長さ当たりの水温上昇率は, 経時的に上昇 してしだいに安定してくるが，単位時間当たりのそれは 逆に急激に減少する.

（4）単位長さ当たりの水温上昇率は，流入口より一 定であり位置的変化はほとんど認められないが, 単位時 間当たりのそれは流入口より離れるほど大きくなる.

（5）水温上昇率は, 時間・位置的にも流速による影 響を強く受ける.

（6）理論・解析結果よりパイプ壁面熱伝達率を理論 的に決定することが可能となった。 
（7）パイプ壁面熱伝達率の時間依存性は, ごく初期 を除いて十分小さく，一方，位置的には流入端で大きく それより離れると減少するが，しだいに一定値となって くる.

（８） パイプ壁面熱伝達率は流速の増大に伴ってやゃ 大きくなるもののそれの影響は顕著ではない.

ここで述べた解析手法は, 現状では複雑な三次元伝熱 場にそのまま適用することは解析上難しいと思われる が，従来技術と併せ応用することによってもこの種の予 測・評価精度を十分向上させ得るものと考える.

最後に, 本実験を遂行するにあたり多大な協力を得た

（株）熊谷組技術研究所 松村哲夫氏に謝意を表します.

\section{参 考 文 献}

1) 田辺忠顕・山川秀次・渡辺 朗：パイプクーリングにお ける管壁面の熱伝達率の決定ならびに冷却効果の解析, 土木学会論文報告集, 第 343 号, pp. 171 179, 1984. 3.

2) 佐藤英明・佐谷靖郎：マスコンクリートにおけるパイプ クーリング効果に関する研究, 土木学会論文集, 第 372 号, pp. $111 \sim 120,1986.8$.

3) Combarnous, M. and Bories, S. : Hydro-thermal convection in saturated porous media, Advance in Hydro- science, edited by Ven te Chow, Vol.10, Academic Press, pp. 231 307, 1975.

4) Sato, K., Shimizu, T. and Ito, Y. : Fundamental study on permeability and dispersion in double porosity rock masses, 5th Int. Conf. on Numerical Methods in Geomechanics, pp. $657 \sim 664,1985.4$.

5）佐藤邦明 - 伊藤 洋 : 地下空洞周辺の伝熱に関する研究, 土木学会論文集, 第 363 号, pp. 97 106, 1985.11.

6）熟津久一郎・田中義一・池川昌弘：変形 FLIC 法による 非圧縮粘性流解析, 日本航空宇宙学会誌, 第 27 巻, 第 307 号, pp. 26 34, 1979. 8.

7）足立武司・过村玄隆・今泉全通：分岐集合部を有する管 内非定常流の一解析法, 日本機械学会論文集 (第 2 部), 43 巻, 366 号, pp. 596 602, 1977. 2 .

8）廣瀬直喜：流体力学における計算機実験の方法とその応 用, 日本航空宇宙学会誌, 第 20 巻, 第 277 号, pp. 25 38, 1972.12 .

9）伊藤 洋 - 佐藤邦明 - 清水昭男 : 放射性核種移行問題に おける変形 FLIC 法の安定性と精度について, 土木学会 第 41 回年次学術講演会 II 部門, pp. 201 202, 1986.11.

10） 日本コンクリート工学協会：マスコンクリートの温度応 力研究委員会報告書, 技報堂出版, pp. 3 7, 1985.11.

(1987.7.6 · 受付) 